\title{
RESEARCH PAPER \\ Propagation and bulblet enhancement of Rhodophiala pratensis from seeds germinated in vitro
}

\author{
Carolina Salazar ${ }^{1}$, Felipe Landeros ${ }^{1}$, Evelyn Bustos ${ }^{2}$, Paulina Bravo 1 , Claudia \\ Pérez $^{2}$, José Becerra ${ }^{2}$, Darcy Ríos ${ }^{1}$, and Matilde Uribe ${ }^{1}$ \\ ${ }^{1}$ Universidad de Concepción, Facultad de Ciencias Forestales, Centro de Biotecnología, Laboratorio de \\ Cultivo de Tejidos. Concepción, Chile. \\ ${ }^{2}$ Universidad de Concepción, Facultad de Ciencias Naturales y Oceanográficas, Departamento de Botánica, \\ Laboratorio de Química de Productos Naturales. Concepción, Chile.
}

\begin{abstract}
C. Salazar, F. Landeros, E. Bustos, P. Bravo, C. Pérez, J. Becerra, D. Ríos, and M. Uribe. 2019. Propagation and bulblet enhancement of Rhodophiala pratensis from seeds germinated in vitro. Cien. Inv. Agr. 46(1): 12-22. Rhodophiala pratensis is an endemic geophyte from Chile with great importance to the national market of cut flowers and potted and garden plants. However, many geophytes have conservation issues and are considered endangered species. Efficient and controlled propagation techniques have been useful for the commercial production of this species and for its conservation. A micropropagation protocol using seeds was developed to determine an optimum method to increase bulb production rates and plant production. The effect of sucrose levels in the medium on the growth of bulbs was tested in vitro $\left(30,60\right.$ and $\left.90 \mathrm{~g} \mathrm{~L}^{-1}\right)$. Then, the effects on shoot and bulb induction of the cytokinin BAP at concentrations of $1.0,2.0$ and $4.0 \mathrm{mg} \mathrm{L}^{-1}$ with the auxin NAA at concentrations of 0.1 , 1.0 and $2.0 \mathrm{mg} \mathrm{L}^{-1}$ were analyzed. The germination rate after eight weeks increased to $86 \%$ with very low contamination (7\%). Bulb growth increased when high levels of sucrose were added to the medium; the optimum sucrose concentration was $90 \mathrm{~g} \mathrm{~L}^{-1}$. Acclimatization was successful, with a plant survival rate of $63 \%$ and an average bulb growth of $0.5 \mathrm{~cm}$. This is the first study to demonstrate the possibility of propagating $R$. pratensis seeds in vitro.
\end{abstract}

Keywords: Endemic species, germination, Rhodophiala pratensis, sucrose.

\section{Introduction}

The geographic isolation of Chile has allowed the development of a wide diversity of unique botanical species that do not exist anywhere else in the world (Olate, 2006). Among them are geophytes, which are characterized by underground storage

Received Aug 29, 2017. Accepted Mar 04, 2019.

Corresponding author: claudiaperez@udec.cl organs, such as bulbs, corms, rhizomes and tubers, and which are one of the groups with the highest number of native species distributed throughout the country. Of a total of 180 geophyte species, $90 \%$ are of endemic origin (Bridgen et al. 2001). Most Chilean geophytes are monocotyledons, represented by nine families (Bridgen et al. 2001). Such is the case for the Amaryllidaceae, which have traditionally supplied many petaloid monocotyledons to the world. Their fast, easy and 
economical reproduction method has positioned Chile as the third largest floriculture exporter in South America, after Colombia and Ecuador (Verdugo, 2013). In this family, the Rhodophiala $C$. Presl genus stands out, which includes native Chilean and Argentinean species with great ornamental potential due to their large, colorful, red, pink, orange and yellow flowers, which can be marketed as potted plants or as cut flowers (Baeza et al. 2012).

In Chile, the genus extends from the Atacama Region to the Los Lagos Region, with 26 native species (Muñoz et al. 2011). However, most Rhodophiala species grow in isolated and restricted areas, making harvest and commercialization difficult, and are endangered due to habitat destruction (Fuenteset et al., 2007). Rhodophiala pratensis (Poepp.) Traub, a vulnerable species located mainly in the Biobío Region, is constantly threatened by habitat transformation due to agricultural and urban development (Ravenna et al. 1998). Conservation of this species through rapid and efficient vegetative propagation is necessary for commercial use and ex situ conservation. Conventional propagation techniques for ornamental purposes have been used to recover other endangered bulbous plant species; however, like in other Amaryllidaceae species, vegetative propagation of $R$. pratensis through bulbs is very slow and inefficient Schiappacasse et al. 2003). An example is Herbertia lahue (Mol.) Goldbl., which generates 1.13 bulblets per bulb, which is within the expected propagation range (Morales et al. 2007). Other Chilean geophyte species, such as Calydorea xiphioides Poepp. and Leucocoryne coquimbensis F. Phil (Kim et al. 1998), produced 1.5 and 1.1 to 1.6 bulbs per mother bulb, respectively (Bridgen et al. 2001, Morales et al. 2007).

In this context, in vitro micropropagation is a viable alternative for rapid and effective production, increasing the number of individuals cultivated in a shorter time, avoiding excessive species exploitation and contributing to species conservation (Vetchinkina et al. 2012). For bulbous species, such as Traubia modesta (Phil.) Ravenna (Paredes et al. 2014), Cyrtanthus clavatus (L'Hérit) R.A. Dyer and C. spiralis Burch. ex Ker Gawl, as well as some Rhodophiala species (Jara et al. 2007, Muñoz et al. 2009), the most widely used in vitro propagation method is the twin-scale technique.

However, another possible in vitro propagation technique is seed germination in a sterile medium to obtain contamination-free in vitro seedlings that would serve as a starting point (establishment phase) for micropropagation protocols, callus induction and cell suspension culture (Rodrigo et al. 2006).

In vitro germination of Rhodophiala species using Plant Preservative Mixture (PPM) has been carried out for $R$. bifida (Herb.) Traub only, obtaining $100 \%$ germinated seeds free of contamination (Rodrigoet et al., 2006). This study focused on Rhodophiala pratensis in order to develop a micropropagation protocol to obtain complete plants. A concentration of 6-benzylaminopurine (BAP), sucrose and naphthalene acetic acid was investigated for its effects on bulb production and growth. This is the first reported in vitro culture for this species.

\section{Materials and methods}

\section{Plant material, disinfection and establishment}

Complete $R$. pratensis plants were collected between January and February 2014, during the flowering period, in the Botanical Garden of Concepcion University, Hualpen district (S36 47'32" W73 $\left.05^{\prime} 44^{\prime \prime}\right)$, Concepción, Chile. Bulbs and seeds were separated and stored at $4{ }^{\circ} \mathrm{C}$ until in vitro establishment.

Seeds were washed with running water and commercial detergent. Then, under aseptic conditions, samples were disinfected with $70 \%$ ethanol for 2 min followed by 3 rinses with distilled sterile water (DSW). Subsequently, they were immersed in commercial chlorine at $70 \%(\mathrm{v} / \mathrm{v})$ with 2 drops 
of commercial surfactant (Quik ${ }^{\circledR}$ ) for $15 \mathrm{~min}$, and then 3 rinses were performed with DSW for 5 min each rinse.

\section{Culture conditions}

Seeds were left for $48 \mathrm{~h}$ in $200 \mu \mathrm{M}$ gibberellic acid $\left(\mathrm{GA}_{3}\right)$ to be seeded without seed coats in vials of $30 \mathrm{~mL}$ culture medium (Murashige and Skoog, 1962) with macronutrients diluted to $25 \%\left(\mathrm{MS}^{1 / 4}\right)$, supplemented with $30 \mathrm{~g} \mathrm{~L}^{-1}$ sucrose, $5 \mathrm{~g} \mathrm{~L}^{-1}$ bacteriological agar (Duchefa) and $0.116 \mathrm{~g} \mathrm{~L}^{-1}$ vitrofural (bactericide/ fungicide) with a $\mathrm{pH}$ adjusted to 5.8. Samples were incubated in a growth chamber at $25 \pm$ $1{ }^{\circ} \mathrm{C}$ with $55 \%$ relative humidity and a $50 \mu \mathrm{mol}$ $\mathrm{m}^{-2} \mathrm{~s}^{-1}$ photonic flux density for 2 weeks in the dark until the appearance of cotyledons and were subsequently subjected to a photoperiod of $16 \mathrm{~h}$ light and $8 \mathrm{~h}$ darkness.

The experimental unit was 5 seeds per flask with 30 replicates. Qualitative variable analysis was performed by means of descriptive statistics, evaluating germination percentages of contaminated seeds and survival at 4 and 8 weeks after its introduction in vitro.

Biomass increase/bulblet growth in vitro

To evaluate the effect of different sucrose concentrations on the size and biomass increases (weight) of formed bulbs, the germinated seeds were established in MS mediums with 30, 60 and $90 \mathrm{~g} \mathrm{~L}^{-1}$ sucrose, with complete macronutrients supplemented with $0.5 \mathrm{~g} \mathrm{~L}^{-1}$ polyvinyl pyrrolidone (PVP, Calbiochem ${ }^{\mathrm{TM}}$ ) antioxidant, $5 \mathrm{~g} \mathrm{~L}^{-1}$ bacteriological agar and $0.16 \mathrm{~g} \mathrm{~L}^{-1}$ vitrofural. Explants were maintained for 8 weeks in a $16 \mathrm{~h}$ light and $8 \mathrm{~h}$ darkness photoperiod, with subcultures in fresh medium every 30 days. Increases in bulb size at the beginning and end of the test (length) were evaluated, as well as the initial and final fresh weight (iFW-fFW). The experimental unit corresponded to 4 explants with 15 replicates per treatment arranged in glass containers with 30 $\mathrm{mL}$ culture medium.

\section{Influence of NAA and BAP on bulblet proliferation.}

After the increase in biomass, half of the cultivated bulbs were subjected to different combinations and concentrations of growth regulators (Table 2) to induce multiplication, new bulb formation and shoot development. Explants were maintained in the presence of growth regulators for a period of 8 weeks in the growth chamber. The number of bulbs, number of buds formed and growth index $\left(\mathrm{ICB}=\mathrm{FW}_{\mathrm{f}}-\mathrm{FW}_{\mathrm{i}}\right) / \mathrm{FW}_{\mathrm{i}}$ were evaluated at the end of this period. The experimental unit consisted of 4 replicates with 4 explants per treatment. Subsequently, formed bulbs were transferred to basal DM medium (supplemented with sucrose $90 \mathrm{~g} \mathrm{~L}^{-1}$ ) without hormones to evaluate the residual effect of phytohormones for a period of 30 days. At the end of this period, the following parameters were evaluated: number of new bulblets, number of leaves, length of leaves and bulbs, diameter and fresh weight. Remains were maintained in three treatments with sucrose $\left(30,60,90 \mathrm{~g} \mathrm{~L}^{-1}\right)$ and evaluated at the end of the trial.

\section{Acclimatization}

In vitro explants in both trials spontaneously formed roots during 8 weeks in media without hormonal treatments. Samples were extracted from the culture medium under aseptic conditions in a laminar flow chamber, and the seedlings were washed with DSW to remove culture medium residues. Finally, samples were transplanted into presterilized plastic trays containing perlite, vermiculite and peat (1:1:1) and sealed to maintain moisture inside the trays. The substrate was moistened with DSW and settled for a period of 2 weeks in a growth chamber at $25 \pm 1{ }^{\circ} \mathrm{C}$ under a photoperiod of $16 \mathrm{~h}$ light and $8 \mathrm{~h}$ darkness. Ir- 
rigation with DSW was performed every 7 days. Then, $75 \%$ of the hermetic system was opened so that seedlings had more contact with the environment. After 4 weeks, the system was completely opened to enrich the plants with $1 / 4$ macronutrient MS medium every 14 days.

\section{Statistical Analysis.}

For the hormonal effect and sucrose concentration analysis, a completely randomized design with a factorial arrangement with two factors and two levels was performed using analysis of variance (ANOVA), which allowed us to identify if there were statistically significant differences between the means. Subsequently, an LSD or Duncan's test was used in continuous quantitative variables. The results were compared to a control sample. All statistical tests were performed with a $95 \%$ confidence level.

\section{Results and Discussion}

Plant material, disinfection and establishment.

As reported in other studies of species belonging to the Amaryllidaceae family, the in vitro multiplication of these species has been slow and highly dependent on genotype (Jara et al. 2001). In addition, twin scaling is the most common propagation technique used due to its effect on the number of bulbs formed; however, many studies show high rates of contamination by bacteria and fungi with this technique, leading in some cases to plant material loss (Ferrando, 2002). Therefore, in vitro multiplication with seeds is an alternative that allows the maintenance of a germplasm bank for these species, reducing contamination rates (Muñoz et al. 2009).

For the species under study, the percentage of germination at 4 weeks was $65 \%$, with contamination reaching $6 \%$. After 8 weeks of culture, the percentage of germinated seeds increased to $86 \%$, and contaminated seeds increased by $1 \%$ (Fig. 1). Virtually all plants formed bulblets in normal form, whose diameter varied between 0.1 to $0.8 \mathrm{~cm}$. The bulblets presented, on average, 3 leaves and a root system, developed with an average of three roots per bulb. Germination percentages obtained through seeds from the studied population are comparable to those achieved by Rodrigo et al. (2006) and Maritano et al. (2008) for R. bifida and are similar to or higher than those achieved by Jara et al. (2001) with $R$. montana, $R$. bagnoldii and $R$. splendens species.

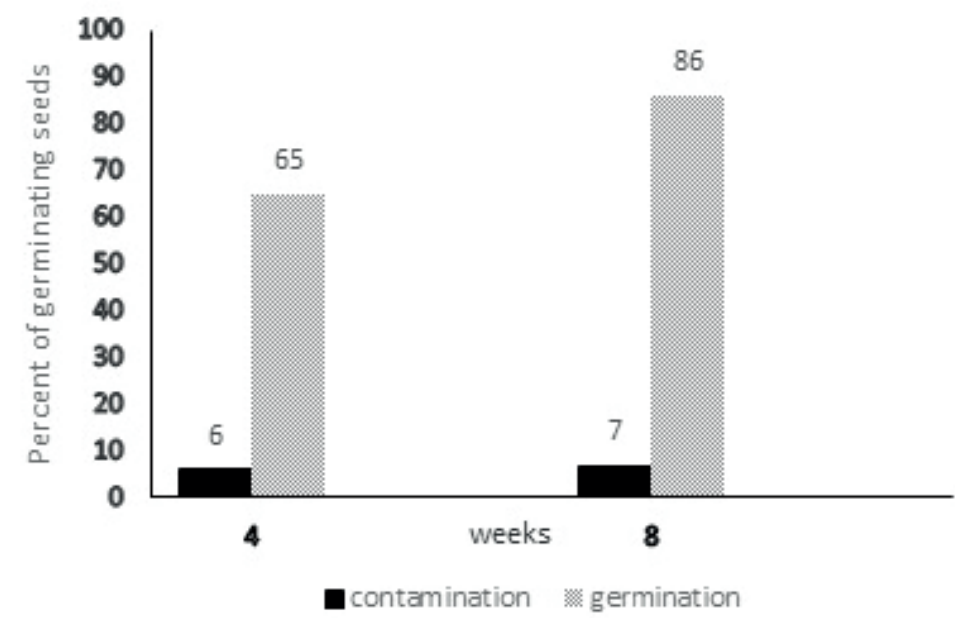

Figure 1. In vitro seed germination and contamination of $R$. pratensis. 
Gibberellins are directly involved in the control and promotion of seed germination. Gibberellic acid $\left(\mathrm{GA}_{3}\right)$ can break seed latency and replace the need for environmental stimuli, such as light and temperature (Araya et al. 2000). The use of $200 \mu \mathrm{M}$ gibberellic acid promoted $R$. pratensis seed germination. Gibberellins specifically increase cellular elongation, making it possible for roots to grow through seed coatings. Seeds presented null to little innate dormancy since they nearly all germinated within a month after harvesting, verifying that the species germinates without the need for cold stratification. $R$. pratensis propagation is important because the economic value of the species is not limited to its ornamental potential but also has pharmacological value due to the alkaloids characteristic of geophytes and, in particular, the Amaryllidaceae family (Torras-Claveria et al. 2013).

It is necessary to adequately disinfect plant material prior to in vitro introduction. Surfaces are exposed to fungi, bacteria and yeasts, which can cause considerable losses during micropropagation and consequently reduce regeneration. These microorganisms compete for nutrients and adversely affect the cultivation or establishment of explants (Azofeifa, 2009). The contamination percentage obtained in this study was low (7\%), which demonstrates the efficiency of the disinfection method and evidence of seed viability. The sterilization regime applied was effective; the number of seeds disinfected was $93 \%$. This regime has the advantage that the material remains in good sanitary condition to continue multiplying plants under similar conditions or to use the material for other purposes.

Biomass increase/bulblets growth in vitro.

To produce an increase in biomass or bulblet weight in vitro, the application of sucrose has shown a significant effect on final bulblet weight (Mujica and Mogollón, 2004). From the explants grown at different sucrose concentrations, a significant effect of sucrose was observed on final bulb weight after 8 weeks of culture (Fig. 2), producing increased biomass levels with increased sucrose concentrations. Other parameters evaluated did not show significant differences or growth suppression.

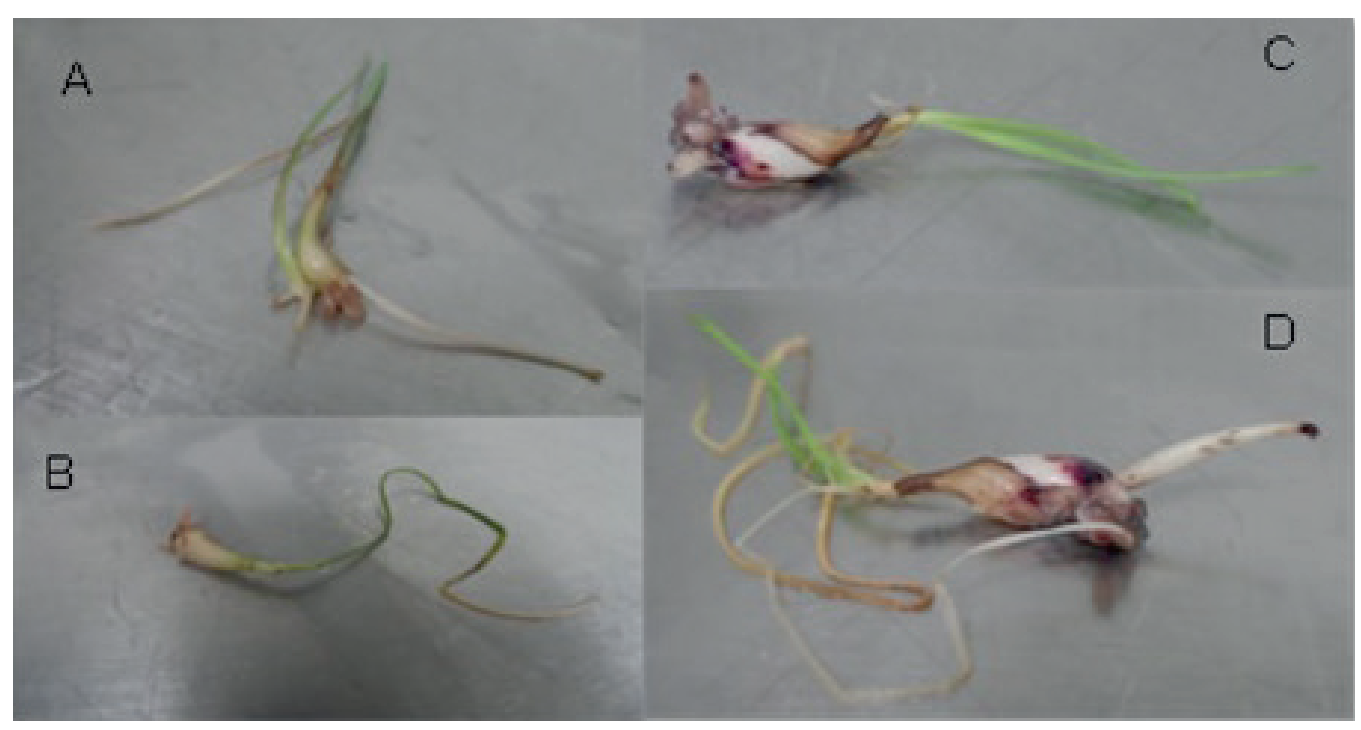

Figure 2. Effect of different concentrations of sucrose on bulblet growth. A-B. Bulblets in $60 \mathrm{~g} \mathrm{~L}^{-1}$ sucrose. C-D. Bulblets in $90 \mathrm{~g} \mathrm{~L}^{-1}$ of sucrose. 
The use of the highest sucrose concentration $\left(90 \mathrm{~g} \mathrm{~L}^{-1}\right)$ produced the highest biomass levels (Table 1), and the total number of bulbs was not affected by the different sucrose concentrations used at 8 weeks. This effect relates to the study by Sellés et al. (1997) and Santos et al. (2002), who reported that $90 \mathrm{~g} \mathrm{~L}^{-1}$ sucrose treatment was the best for increasing Narcissus confusus and $N$. asturiensis bulb diameters, demonstrating that there is a positive effect of sucrose on cellular tissue morphology as well as on photosynthetic system activity. Prado et al. (2010) mention that the increase in growth of the bulb is attributable to a greater availability of carbon structures for producing new cellular components, which increases with sugar concentrations until it reaches an optimum point after which any additional amount of sugar has no influence on plant morphogenesis.

These results are similar to those obtained after 12 weeks of $R$. bagnoldii cultivation, in which a significant effect of sucrose on the weight and number of bulbs produced was observed (Olate 2006). The same results were also evidenced by twin-scaled and single-scaled micropropagated Cyrtanthus hybrid 'Orange Gem' $\times$ C. eucallus R.A. Dyer (Hong and Lee 2012). Unlike previous studies, Tipirdamaz (2003) reported that the use of $30 \mathrm{~g} \mathrm{~L}^{-1}$ to $60 \mathrm{~g} \mathrm{~L}^{-1}$ sucrose does not statistically affect Galanthus ikariae bulb growth. Therefore, the ability of plant tissues to use carbohydrates varies among species and even among explants. It also depends on the ability of the tissue to absorb, transport and metabolize carbohydrates (Cheesman et al. 2010).

\section{Influence of NAA and BAP on shoot proliferation.}

It is known that the correct balance of cytokinins and auxins plays an important role during shoot proliferation. No studies exist on the positive effect of auxins and cytokinins on the proliferation of shoots and bulblets for $R$. pratensis. In the present study, no new bulb formation was obtained from the initial bulbs after 8 weeks in media supplemented with hormones. There were also no significant differences between hormonal treatments in the number of leaves formed or the bulb growth rates. The bulb growth rate was 1.8 in the presence of $2 \mathrm{mg} \mathrm{L}^{-1} \mathrm{NAA}$ and $2 \mathrm{mg} \mathrm{L}^{-1} \mathrm{BAP}$, which was lower than the growth rate in the other treatments (Table 2). A color change from white to dark purple was observed, and necrosis was later observed. According to Seemann (1993), explant browning is a problem that relates to the release and oxidation of polyphenols in the media due to stress caused by high hormone levels, resulting in products that are toxic to the explant and that can even lead to necrosis.

Bulbification depends highly on the concentration of growth regulators and sucrose, among other factors.The role of cytokinins in conventional micropropagation using solid media has been analyzed for several Rhodophiala genus species, and very low multiplication coefficients have been reported (Jara et al. 2007). Slabbert et al. (1993), working with Amaryllidaceae family species, found that the highest production rates of shoots and bulbs occurred when cultivated in media without cytokinins. Similar results were obtained by Jara et al. (2007), in which the effect of media

Table 1. Effect of different sucrose treatments on biomass and size of bulbs formed after 8 weeks of cultivation.

\begin{tabular}{lcccccc}
\hline $\mathrm{S}\left(\mathrm{g} \mathrm{L}^{-1}\right)$ & $\mathrm{W}_{\mathrm{i}}(\mathrm{cm})$ & $\mathrm{W}_{\mathrm{f}}(\mathrm{cm})$ & $\mathrm{L}_{\mathrm{i}}(\mathrm{cm})$ & $\mathrm{L}_{\mathrm{f}}(\mathrm{cm})$ & $\mathrm{FW}_{\mathrm{i}}(\mathrm{g})$ & $\mathrm{FW}_{\mathrm{f}}(\mathrm{g})$ \\
\hline 30 & $0.22 \pm 0.09$ & $0.25 \pm 0.12$ & $0.44 \pm 0.13$ & $0.44+0.14$ & $0.06 \pm 0.10$ & $0.03 \pm 0.11 \mathrm{a}$ \\
60 & $0.20 \pm 0.10$ & $0.26 \pm 0.09$ & $0.38 \pm 0.11$ & $0.38+0.11$ & $0.07 \pm 0.15$ & $0.04 \pm 0.13 \mathrm{a}$ \\
90 & $0.20 \pm 0.08$ & $0.21 \pm 0.08$ & $0.46 \pm 0.19$ & $0.50+0.21$ & $0.11 \pm 0.18$ & $0.07 \pm 0.15 \mathrm{~b}$ \\
\hline
\end{tabular}

S: Sucrose; Wi: Initial width; Wf: Final width; Li: Initial length; Lf: Final length; FWi: Initial fresh weight; FWf: Final fresh weight. 
Table 2. Effect of different hormonal treatments on R. pratensis bulbs from seeds.

\begin{tabular}{lcccccc}
\hline NAA $\left(\mathrm{mg} \mathrm{L}^{-1}\right)$ & $\mathrm{BAP}\left(\mathrm{mg} \mathrm{L}^{-1}\right)$ & $\mathrm{N}^{\circ} \mathrm{L}_{\mathrm{i}}$ & $\mathrm{N}^{\circ} \mathrm{L}_{\mathrm{f}}$ & $\mathrm{N}^{\circ} \mathrm{B}_{\mathrm{i}}$ & $\mathrm{N}^{\circ} \mathrm{B}_{\mathrm{f}}$ & $\mathrm{BGI}$ \\
\hline 0,0 & 0,0 & $2.16 \pm 0.50$ & $1.25 \pm 0.55 \mathrm{ab}$ & $1.0 \pm 0.0$ & $1.0 \pm 0.0$ & 2.0 \\
1,0 & 2,0 & $3.33 \pm 1.46$ & $1.00 \pm 0.61 \mathrm{~b}$ & $1.22 \pm 0.8$ & $1.22 \pm 0.8$ & 2.0 \\
2,0 & 2,0 & $3.96 \pm 1.65$ & $2.11 \pm 0.23 \mathrm{a}$ & $1.75 \pm 0.98$ & $1.75 \pm 0.98$ & 1.8 \\
0.1 & 1,0 & $2.75 \pm 1.33$ & $1.5 \pm 0.66 \mathrm{ab}$ & $1.33 \pm 0.73$ & $1.33 \pm 0.73$ & 2.1 \\
0.1 & 4,0 & $2.08 \pm 0.88$ & $1.75 \pm 0.39 \mathrm{ab}$ & $1.08 \pm 0.49$ & $1.08 \pm 0.49$ & 2.1 \\
\hline
\end{tabular}

$\mathrm{N}^{\circ} \mathrm{L}_{\mathrm{i}}$ : Number of initial leaves; $\mathrm{N}^{\circ} \mathrm{L}_{\mathrm{f}}$ : Number of final leaves; $\mathrm{N}^{\circ} \mathrm{B}_{\mathrm{i}}$ : Number of initial bulblets; $\mathrm{N}^{\circ} \mathrm{B}_{\mathrm{f}}:$ Number of final bulblets; BGI: Bulblet growth index; NAA: 1-naphthalene acetic acid; BAP: 6-Benzylaminopurine

with growth regulators and carbohydrates was not significant for sprouting and/or bulbification in $R$. montana scales. The results of the effects of a combination of hormones on the proliferation of $R$. pratensis shoots reinforce the conclusion that BAP plus NAA would not have a significant effect on shoot proliferation.

The bulbs remained in different sucrose concentrations during the second stage of the experiment, without growth regulators. High sucrose concentrations affected bulb growth, inhibiting growth and new bulb formation (Table 3). However, unlike what happens in the presence of hormones, a maximum number of 3 bulbs per explant were obtained in the presence of $30 \mathrm{~g} \mathrm{~L}^{-1}$ sucrose (Fig. 3). The highest percentage of bulblet biomass increase was obtained $(97.5 \%)$ at this concentration. Regarding the other parameters evaluated, there are significant differences in shoot length and fresh weight. The results agree with those obtained by Ferrando (2002) for different species of daffodils, in which the development of adventitious bulbs was feasible in DM medium culture in the dark and without the addition of growth regulators, and those reported by Colque et al. (2002) for Eucrosia stricklandii (Baker) Meerow, in which bulbification from twin-scaling was carried out in media lacking growth regulators.

\section{Acclimatization}

Acclimatization is a critical stage often associated with slow growth and significant plant loss (Uzunet et al. 2014). One major problem in plant tissue culture is that plants experience a desiccation jolt just after transplantation. This desiccation can be reduced to a considerable extent by covering the transplanted material with polythene bags to enable plants to survive outside culture vessels. These precautions helped facilitate the establishment and recovery of transplanted material in a short time under growth room conditions (Ozel et al. 2015). Acclimatization in the current study was successful; the percentage of survival of the seedlings after 2 months of acclimatization was $63 \%$, producing on average for each bulb 2 leaves that were $17.6 \mathrm{~cm}$ long and 3 roots that were $6 \mathrm{~cm}$ long, with an average bulb width of $0.5 \mathrm{~cm}$ (Fig. 4). After 8 months in a greenhouse, flowering was observed, as well as increases in the number and length of leaves and roots.

The main conclusions are the following. An efficient and reproducible method was developed

Table 3. Effect of sucrose on the regeneration of bulblets in medium without hormones

\begin{tabular}{lcccccc}
\hline $\mathrm{S}\left(\mathrm{gL}^{-1}\right)$ & $\mathrm{N}^{\circ} \mathrm{S}$ & $\mathrm{BD}(\%)$ & $\mathrm{BW}$ & $\mathrm{BL}$ & $\mathrm{SL}$ & $\mathrm{FW}$ \\
\hline 30 & $2.98 \pm 1.63 \mathrm{a}$ & 31.3 & $0.20 \pm 0.08$ & $0.60 \pm 0.24$ & $6.48 \pm 3.06 \mathrm{a}$ & $0.066 \pm 0.04 \mathrm{a}$ \\
60 & $2.17 \pm 1.70 \mathrm{a}$ & 26.9 & $0.19 \pm 0.09$ & $0.50 \pm 0.24$ & $3.59 \pm 2.73 \mathrm{~b}$ & $0.043 \pm 0.03 \mathrm{~b}$ \\
90 & $1.28 \pm 0.95 \mathrm{~b}$ & 11.5 & $0.22 \pm 0.14$ & $0.50 \pm 0.34$ & $2.03 \pm 1.83 \mathrm{~b}$ & $0.041 \pm 0.03 \mathrm{~b}$ \\
\hline
\end{tabular}

S: Sucrose concentration; $N^{\circ} \mathrm{S}$ : Number of shoots, BD: Bulblet diameter (cm); BW: Bulblet width; BL: Bulblet length (cm); SL: Shoot length (cm); FW: Fresh weight 
for the propagation of $R$. pratensis using seeds to obtain a high percentage of germination and complete plants. This study represents the first report of in vitro regeneration for this species, which can be valuable for commercial production and germplasm conservation of endemic species.

\section{Acknowledgements}

This study was founded throught the proyect FONDEF CA13i10142. Finally the authors thanks the contributions of the proyect AFB 170007; 18VIPM-92367y.

Figure 3. Bulblet multiplication in basal medium without growth regulators. A. Biomass growth and induction of roots. B.C.D. Increase in the number of bulblets from one explant.
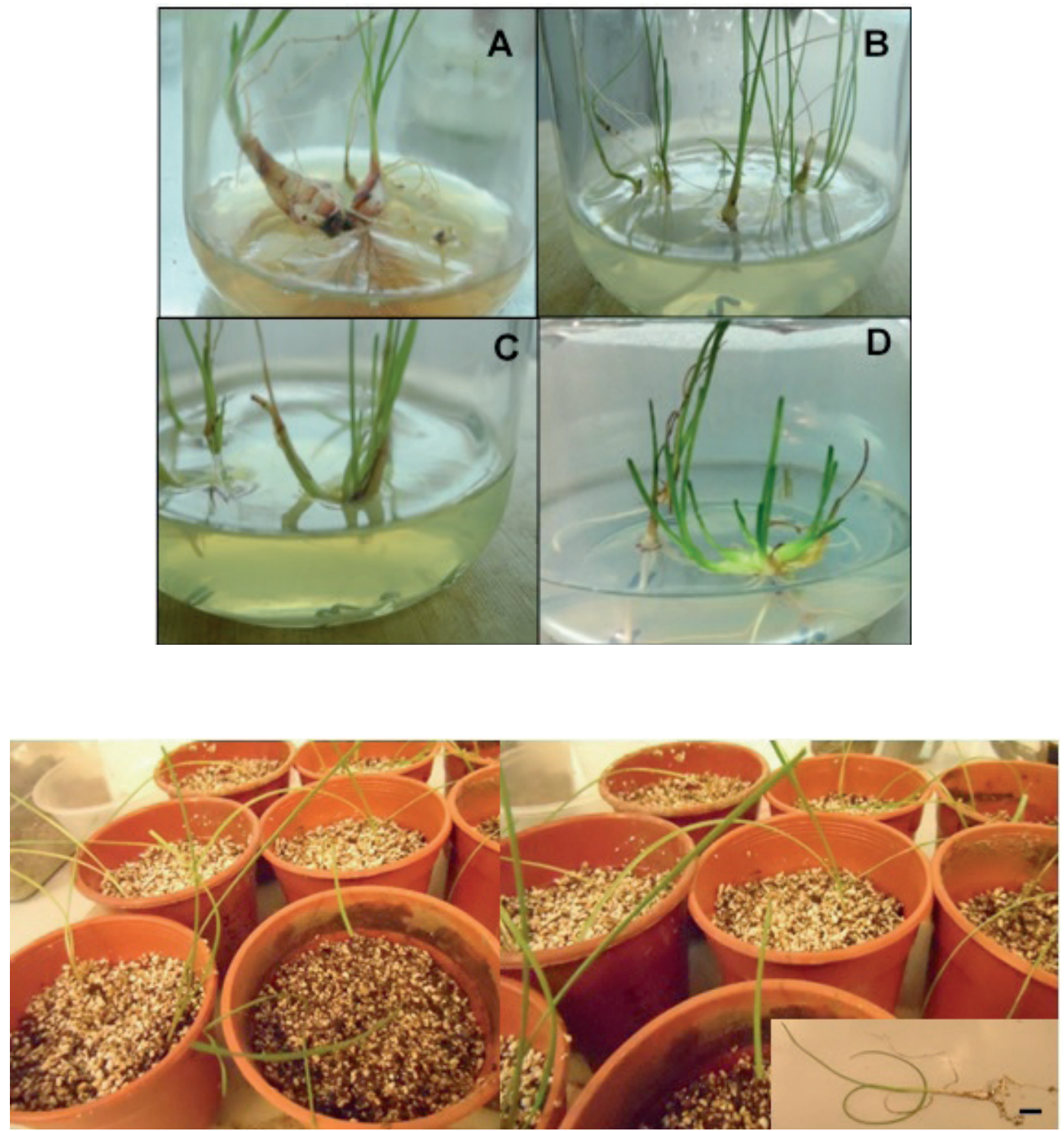

Figure 4. Plants of $R$. pratensis obtained from in vitro culture. Bar $=1 \mathrm{~cm}$ 


\section{Resumen}

C. Salazar, F. Landeros, E. Bustos, P. Bravo, C. Pérez, J. Becerra, D. Ríos, y M. Uribe. 2019. Propagation and bulblet enhancement of Rhodophiala pratensis from seeds germinated in vitro. Cien. Inv. Agr. 46(1): 12-22. Rhodophiala pratensis es un planta geófita endémica de Chile con gran importancia para el mercado nacional de flores, macetas y plantas de jardín. Sin embargo, muchas de estas geófitas tienen problemas de conservación, siendo consideradas especies en peligro de extinción. Para la conservación y producción comercial de esta especie, las técnicas de propagación eficiente y controlada han sido muy útiles. Por esto, se desarrolló un protocolo de micropropagación utilizando semillas para determinar un método óptimo que permita aumentar las tasas de producción de bulbos y la producción de plantas. Se probó el efecto de distintas concentraciones de sacarosa en el medio de cultivo sobre el crecimiento in vitro de los bulbos $\left(30,60\right.$ y $\left.90 \mathrm{~g} \mathrm{~L}^{-1}\right)$. A continuación, se analizaron los efectos de la citoquinina BAP en concentraciones de 1.0, 2.0 y $4.0 \mathrm{mg} \mathrm{L}^{-1}$ con auxina NAA en concentraciones de 0.1 , 1.0 y $2.0 \mathrm{mg} \mathrm{L}^{-1}$ en la inducción de brotes y bulbos. La tasa de germinación después de ocho semanas aumentó a $86 \%$ con una contaminación muy baja (7\%). El crecimiento del bulbo aumentó cuando se añadieron altos niveles de sacarosa al medio, con una concentración óptima de $90 \mathrm{~g} \mathrm{~L}^{-1}$. La aclimatación tuvo éxito con una supervivencia de plantas del $63 \%$, con un promedio de crecimiento de bulbo de $0.5 \mathrm{~cm}$. Esta es la primera investigación que demuestra la posibilidad de propagar semillas de $R$. pratensis in vitro.

Palabras clave: Especies endémicas, germinación, Rhodophiala pratensis, sacarosa.

\section{References}

Araya E., L. Gómez, N. Hidalgo, y R. Valverde. 2000. Efecto de la luz y del ácido giberélico sobre la germinación in vitro de Jaul (Alnus acuminata). Agronomía Costarricense 24:75-80.

Azofeifa, A. 2009. Problemas de oxidación y oscurecimiento de explantes cultivados in vitro. Agronomía Mesoamericana 20:153-175.

Baeza C., E. Ruiz, F. Almendras, y P. Peñailillo. 2012. Estudio comparativo del cariotipo en especies de Miltinea Ravenna, Phycella Lindl. y Rhodophiala C. Presl (Amaryllidaceae) de Chile. Rev CA UNCUYO 44(2):193-205.

Bridgen M.P., E. Olate, and F. Schiappacasse. 2001. Flowering geophytes of Chile. Proceedings of the 8th International Symposium on Flowerbulbs. ISHS. Acta Hortic 570:75-80. doi: 10.17660/ ActaHortic.2002.570.6

Cheesman L., J.F. Finnie, and J. Van Staden. 2010. Eucomis zambesiaca baker: Factors affecting in vitro bulblet induction. South African $\mathrm{J}$ Bot 76(3):543-549. doi: 10.1016/j.sajb.2010.04.004
Colque, R., F. Viladomat, J. Bastida, and C. Codina. 2002. Micropropagation of the rare Eucrosia stricklandii (Amaryllidaceae) by twin-scaling and shake liquid culture. J Hortic Sci Biotechnol 77(6):739-743. doi: 10.1080/14620316.2002.11511566

Ferrando, M. 2002. Multiplicación in vitro de las especies Rhodophiala montana (Phil.) Traub., Rhodophiala rhodolirion (Baker) Traub. y Rhodophiala splendens (Rengifo) Traub. Tesis para optar al grado de Licenciado en Agronomía. Universidad Austral de Chile.

Fuentes, L., F. Schiappacasse, R. Herrera, P. Peñailillo, y H. Vogel. 2007. Evaluación preliminar de las relaciones interespecíficas en Rhodophiala Presl (Amaryllidaceae) mediante marcadores moleculares ISSR. Agro Sur 35(2):47-49.

Hong, J., and A.K. Lee. 2012. Micropropagation of Cyrtanthus 'Orange Gem' $\times$ C. eucallus hybrid. Sci Hortic 142:174-179. doi: 10.1016/j.scienta.2012.05.016

Jara G., P. Seemann, M. Muñoz, R. Riegel, F. Schiappacasse, P. Peñailillo, y A. Basoalto. 2001. 
Aplicaciones biotecnológicas en el mejoramiento genético de cuatro especies de Rhodophiala chilenas. Proyecto FIA código Biot 01-A-071, pp 63-64.

Jara G., P. Seemann, y M. Muñoz. 2007. Cultivo in vitro y aclimatización de plántulas de Rhodophiala montana. Agro Sur 35(2):50-52.

Kim, H.H., K. Ohkawa, and E. Nitta. 1998. Effects of bulb weight on the growth and flowering of Leucocoryne coquimbensis F. phill. Acta Hortic 454:341-346. doi: 10.17660/ActaHortic. 1998.454 .40

Maritano, P.F., M.C. Pérez de la Torre, P.A. Marinangeli, y A.S. Escandón. 2008. Ensayos preliminares para el estudio de una amarilidácea nativa con potencial ornamental. Cultivo in vitro y caracterización molecular de Rhodophiala bífida (Herb.) Traub. Actas del IV Congreso Argentino de Floricultura y 10a Jornadas Nacionales de Floricultura. INTA, Buenos Aires, pp 428-430.

Morales, P., P. Peñailillo, P. Yañez, y F. Schiappacase. 2007. Efecto del peso del bulbo sobre el crecimiento vegetativo y reproductivo de Herbetia lahue (Molina) Goldbl. subsp. Lahue (Iridaceae). Agro Sur 35(2):28-30.

Mujica, H., y N. Mogollón. 2004. Bulbificación in vitro del ajo (Allium sativum L.) con adición de citoquininas y sacarosa en el medio de cultivo. Bioagro 16:55-60.

Muñoz, M., P. Seemann, G. Jara, and R. Riegel. 2009. Influence of vessel type, physical state of medium and temporary immersion on the micropropagation of three Rhodophiala species. Chilean JAR 69(4):581-587. doi: 10.4067/S071858392009000400014

Muñoz, M., R. Riegel, P. Seemann, P. Peñailillo, F. Sciappacasse, and J. Nuñez. 2011. Relaciones filogenéticas de Rhodolirium montanum Phil. y especies afines, basadas en secuencias nucleotídicas de la región ITS y análisis cariotípico. Gayana Bot 68:40-48. doi: 10.4067/S071766432011000100005

Murashige, T., and F. Skoog. 1962. A revised medium for rapid growth and bio assays with tobacco cultures. Physiol Plant 15:473-497. doi: 10.1111/ j.1399-3054.1962.tb08052.x
Olate, E. 2006. Chilean geophytes: micropropagation and cut flower production. Ph.D. diss., University of Connecticut, USA.

Ozel, C.A., K.M. Khawar, F. Unal. 2015. Factors affecting efficient in vitro micropropagation of Muscari muscarimi Medikus using twin bulb scale. Saudi J Biol Sci 22(2):132-138. doi: 10.1016/j.sjbs.2014.09.007

Paredes, K., C. Delaveau, P. Carrasco, C. Baeza, F. Mora, and M. Uribe. 2014. In vitro bulbing for the propagation of Traubia modesta (Amaryllidaceae), a threatened plant endemic to Chile. Cien Inv Agr 41(2):207-214. doi: 10.4067/ S0718-16202014000200007

Prado, C., M. Andrade, A. Villegas, I. Alia, Ó. Villegas, and V. López. 2010. In vitro propagation of Sprekelia formosissima Herbert., a wild plant with ornamental potential. Rev Fitotec Mex 33(3):197-203.

Ravenna, P., S. Steillier, J. Macaya, R. Rodríguez, y O. Zöllner. 1998. Categorías de conservación de las plantas bulbosas nativas de Chile. Boletín del Museo Nacional de Historia Natural, Chile 47:47-68.

Rodrigo, J.M., F.J. Rosselló, P.A. Marinangeli, and N.R. Curvetto. 2006. Germinación in vitro de Rhodophialabifida. Actas del III Congreso Argentino de Floricultura y XII Jornadas Nacionales de Floricultura. INTA, Buenos Aires, pp 428-430.

Santos, A., F. Fidalgo, I. Santos, and R. Salema. 2002. In vitro bulb formation of Narcissus asturiensis, a threatened species of the Amaryllidaceae. J Hortic Sci Biotechnol 77(2):149-152. doi: 10.1080/14620316.2002.11511471

Schiappacasse, F., R. Colque, F. Viladomat, J. Bastida, y P. Codina. 2003. Propagación de bulbosas chilenas ornamentales. Ed Universidad de Talca, Talca. Chile.

Slabbert, M., M. De Bruyn, D. Ferreira, and J. Pretorius. 1993. Regeneration of bulblets from twin scales of Crinum macowanii in vitro. Plant Cell Tissue Organ Cult 33(2):133-141.

Seemann, P. 1993. Utilización de técnicas de micropropagación. In: Barriga P, Neira M (eds) Cultivos no tradicionales. Universidad Austral de Chile. 
Facultad de Ciencias Agrarias. Instituto de Producción y Sanidad Vegetal. Valdivia, pp 87-146.

Sellés, M., S. Bergonon, F. Viladomat, J. Bastida, and C. Codina. 1997. Effect of sucrose on growth and galanthamine production in shoot-clump cultures of Narcissus confusus in liquid-shake medium. Plant Cell Tissue Organ Cult 49(2):129-136.

Tipirdamaz, R. 2003. Rooting and acclimatization of in vitro micropropagated snowdrop (Galanthus ikariae Baker) bulblets. Ziraat Fakultesi Dergisi, Akdeniz Universitesi 16(2):121-126.

Torras-Claveria, L., S. Berkov, C. Codina, and J. Bastida. 2013. Daffodils as potential crops of galanthamine. Assessment of more than 100 ornamental varieties for their alkaloid content and acetylcholinesterase inhibitory activity. Ind Crops Prod 43:237-244.

Uzun, S., A.İ. İlbaş, A. İpek, N. Arslan, and S. Barpete. 2015. Efficient in vitro plant regeneration from immature embryos of endemic Iris sari and I. schachtii. Turk J Agric For 38:348-353.

Verdugo, G. 2013. Flower breeding of native plants: The Chilean experience. In: Facciuto G, Sánchez MI (eds) Proc. VIIth IS on New Floricultural crops, pp 401-406.

Vetchinkina, E.M., I.V. Shirnina, S.Y. Shirnin, and O.I. Molkanova. 2012. Preservation of rare species of plants in genetic collections in vitro. Vestnik Baltijskogo Federal'nogo Universitetaim. I. Kanta 7:109-118. 